\title{
Valuation of ICT Proficiency of Teachers in Actualizing E-learning in Home Economics Education, Ogun State, Nigeria
}

\author{
Sarah Adewunmi James \\ Federal College of Education \\ Nigeria
}

\begin{abstract}
There is need for improvement in the teaching methods in schools from time to time to enhance effective importation of knowledge. This study assessed the competence of Home Economics Teachers in ICT, both secondary schools and higher institutions of learning. Twelve secondary schools were purposely selected. Forty home economics teachers were randomly selected for the study. Structured questionnaire of four-point likert scale was used to assess respondent's ICT competence. The study revealed the teacher's skill in the ability to use ICT facilities, integrate knowledge for new learning situation modeling. The study concludes that Home Economics teachers have to be computer literate as well as been up-to-date in all areas of Home Economics Education. The study recommends that home economics teachers should be internally motivated and capable of continuous learning to ensure systematic improvement of the necessary competencies which guarantee improved school Elearning teaching qualities.
\end{abstract}

\section{Introduction}

In today's modern and technologically evolving world, teachers' responsibilities have become more elaborate as they are expected to be content experts, technology specialists, motivators, cooperative and collaborative learning advocates as well as monitors of student progress [6]. Information and Communication Technologies (ICTs) have proffered greatly to the performance of these roles by the teachers at all educational levels. ICT have expanded the breadth and depth of opportunities within the institutions of learning everywhere in the world.

E-learning on the other hand can be best described as a term that involves a wide-ranging content and instruction methods which now has become a new model of education involving modified and revised curriculum, structure, foundation, teachers professional development, textbooks and exams to provide students with that technological idea and skill to solve problems easily and at a faster rate. In Education, one major useful aspect of ICT is the easy access to the massive amount of educational materials and assets on the internet and online libraries. The networking of teachers, students and others can also give way to an active community sharing information, ideas and strategies [8].

E-learning is an extended form of classroom teaching where learning, either online or offline is facilitated by the use of computer, telecommunication devices, networks, and storage capacity. On top of its easy delivery of information and interactive nature, the main benefit behind using the E-Learning instead of the traditional way is that Learners develop communication as well as personal skills such as autonomy analytical perception, abstraction and others. We can also describe E-learning as an extended method of classroom teaching in which knowledge is impacted on the students, either online or offline which is facilitated by utilizing devices such as computer, telecommunication devices, networks and storage capacity. Even with its simple conveyance of information and intuitive nature, the principle advantage of using E-learning compared to the conventional way of teaching is that Learners improve on communication as well as individual skills such as independence, analytical perception, abstraction etc [5].

The educational curriculum of the senior secondary school in Nigeria has been expanded with the introduction of various new vocational and science subjects. The utilization of suitable methods of technological communication would guarantee more effective and innovative delivery of lessons towards internationalization and applying knowledge for technological improvements.

When we consider the non-stopping and increasingly complex pattern of this data age, the question we all should ask ourselves is not whether Nigeria will move towards the direction of e-learning, but how? Computer education should be presented at the pre-primary through a primary level of education, properly e-learning should be introduced at the secondary level of education and it should be perfected at the tertiary level of education. E-learning is a portion of ICT. We can also say that the concept behind e-learning and the idea of ICT are linked.

According to the ICT Sector Strategy Paper of the World Bank Group, "Information and Communication Technology (ICT) consists of hardware, software, networks, and media for 
collection, storage, processing, transmission, and presentation of information (voice, data, text, and images)" [4]. On the other hand, E-learning refers to the mode of purposely making use of electronic frameworks, systems or computer in improving the process of learning [2]. We can clearly conclude that the existence of ICT set-up in a school will lead to a learning environment for e-learning. It means that the only possibility for e-learning to take place is when the proper ICT infrastructure has been put in place. ICT skill is one of the factors that plays a major role in the development of the economic growth of country.

According to Leonard [5] e-learning simply means electronic learning. We can deduct from that statement that without an electronic device e-learning cannot take place. He went on to tell us that e-learning encompasses all forms of electronically supported teaching and learning. The significance of e-learning resources to the teacher as a curriculum implementer in todays digital age cannot be over emphasized. "The elementary mission of e-learning is to change the ancient procedures and approaches to the curriculum implementation" [9]

Distant learning is another part in which e-learning is significant because the process of teaching and learning becomes accessible from anywhere. Distant education supports learning process and this will allow easy management of materials which helps in creating flexible education methods. Students can easily submit research or assignment from home with ease and at their convenience. Virtual contact amongst teachers and students becomes convenient for both parties.

Current technological developments have called for the need to expose opportunities in e-learning for effective teaching and learning in home economics education. The need for adopting technology-based education is increasing exponentially as schools in Nigeria are craving to catch-up with the trend of technological development but most secondary teachers are found using the obsolete methods of teaching instead of adopting the contemporary technology-driven methods. This practice does not conform to the opinion of Ifeakor and Okoli as cited in Agbor [1] that developed countries have adopted elearning methods in teaching their students. It appears Home economics teachers are not keen in the area of e-learning because they believe the opinion of Terande [9], that computers and other hardware are not available for teaching and learning.

It is expected that home economics teachers should embrace and use the available e-learning facilities for teaching and learning process. Such facilities include computer hardware like CD ROMs, flash drives, printers, scanners, mouse, and computer software, belonging to social media like Facebook, WhatsApp, YouTube, twitter, have knowledge about Wikipedia, goggle, and ability to open and manage an e-mail address. Home economics teachers in a society with availability and provision of internet facilities must not isolate themselves from exposure to these facilities especially at the secondary school level where the students are in jet-age are expected to be computer literate.

The teaching and learning of home economics should involve, according to Anyakoha [3], helping students to determine the problems facing individuals, seek workable solutions, seek means of satisfying individual and family needs, improve goods and services used by families and become responsible and effective member of the family and the community. To achieve these goals, home economics teachers should utilize new technological resources in the teaching and learning process in other to keep pace with the rapid growth and changes in technology.

According to Agbor et al. [1], the five key sectors of e-learning industry include consulting, content, technologies, services and support. In Hedge and Hayward, e-learning is described as an innovative approach for delivering electronically mediated, well designed, learner-centered and interactive learning environments to anyone, anyplace, anytime by utilizing the internet and digital technologies in conjunction with instructional design principles. Agbor et al. [1] described e-learning as a system of learning electronically between or amid people irrespective of distance, time or place. It is not only confined to the use of internet which can be referred to as an online process, but it also involves the use of several electronic media outside the internet or web known as an offline process. E-learning is a driving force for achieving better education in recent times.

Since there is need for regular improvement in teaching and learning of Home Economics, both in Higher Institutions and in Secondary Schools, Home Economics teacher is supposed to be competent in ICT. This will help to increase people creative and intellectual resources, especially in today's information society and gives ample and exceptional opportunities to students to develop capabilities for high quality learning and increase their ability to innovate [4].

\section{Statement of Problem}

Nigeria Educational Research and Development Council (NERDC) introduced a new curriculum in 2008 which made ICT compulsory to secondary school students. This brought fore challenges because some teachers lack knowledge and skill in the use of ICT. Other challenges include lack of ICT facilities such as computer, printer, scanner, internet facilities etc. Okafor and Ejiofor [7] discovered that teachers' use of the resources is very little. Thus, the students have seriously been confined to the four walls of the classrooms and chalk-talk model of teaching employed thereby not giving the students the 
opportunity of moving into the modern acceptable level of education. It could be that teachers appear not concerned about the availability of these resources.

This study therefore seeks to answer the following questions:

- To what extent can a Home Economics teacher in Ogun state use Internet facilities?

- How can the teacher use E-learning to enhance teaching of Home Economics in Secondary Schools?

- How does the school management support Elearning by providing Electricity and Internet facilities?

\section{Research Objectives}

The study specifically aims to

1. Determine to what extent teachers of Home Economics can use Internet facilities.

2. Ascertain how teachers can use E-learning to facilitate the teaching of Home Economics in Schools.

3. Find out the Internet facilities available in schools

\section{Methodology}

The descriptive survey design was utilized for the study. The population of the study consists of all Home Economics teachers in Ogun State public and private schools. According to the 2016 Ogun State ministry of education record, the total number of Home economics teachers is approximately 480 teachers. Because not all schools offer Home Economics as a subject. Purposive Sampling techniques was adopted to select 12 secondary schools while Simple Random Sampling was adopted to select 6 teachers from each of the selected Secondary Schools. The Sample size for the study was 80 teachers. Structured Questionnaire was used to collect data from the respondents. Descriptive statistical procedures were employed in treating the data and the results so obtained formed the basis for the conclusions reached in this paper.

\section{Results}

Responses on the ability of Home Economics teachers to use Internet facilities.

\section{Summary, Conclusion and Policy Recommendation}

This presents a summary of the findings on the valuation of ICT proficiency of teachers in actualizing e-learning in home economics education, Ogun State, Nigeria. The study was done to show the level of access \& knowledge of these teachers in the use of elearning and Internet facilities as a tool to enhance teaching in their schools. The purpose is to round off the study with the summary of findings, conclusions and recommendations.

\section{Summary of Findings}

This section presents the key findings as considered under each objective in the study. The findings indicate that the focus of the study was a sample of Home Economics Teachers in select secondary schools in Ogun state who were willing to give sincere responses to the questionnaires.

The study revealed that Home Economics teachers require the ability to utilize e-learning facilities to improve their mode of content delivery, navigate the internet, open webpage, use social networks on daily basis, as well as use of computer for teaching and giving assignments to students.

The first objective of the study was to determine the ability of Home Economics teachers to use internet for basic activities like emails, social media, internet search as well as basic identification and resolution of problems that occur on computer devices (see Table 1). The responses revealed that $62.5 \%$ can send and reply emails, only $37.5 \%$ of the respondents can use Microsoft word, $68.8 \%$ cannot navigate the Internet, $81.3 \%$ cannot open a webpage and only $6.3 \%$ can identify and resolve problems on computer devices. Results from the respondents show a poor level of knowledge as regards use of the internet and basic Microsoft tool in content delivery. This further validates the claim by Okafor and Ejiofor [7] that Teachers lack adequate knowledge in the use of ICT tools in delivering educational contents to their students. Therefore, this situation does not create an enabling environment for students to derive knowledge in line with modern and acceptable standards.

The second objective of the study was to ascertain how teachers use E-learning facilities to enhance the teaching of Home Economics in schools (see Table 2). The responses revealed that $75 \%$ believe that Elearning helps to express teaching better, $62.5 \%$ confirmed that Proposal and projects can be made easy with students/teachers communications on internet, while $94 \%$ agreed that New and modern food recipes can be obtained through internet services. Results from the respondents further shows that, despite the unavailability of these facilities in the schools, majority of the teachers agreed that - the use of e-learning facilities in very important in the improvement of teaching methods and content delivery to the students. This does not conform to the claim by Terande [9] that Home economics teachers are not keen in the area of e-learning because computers and other hardware are not available for teaching and learning. 
Table 1. Home Economics Teachers Ability to use Internet

\begin{tabular}{|c|c|c|c|c|c|}
\hline & $\begin{array}{l}\text { Home Economics Teachers Ability } \\
\text { to use Internet }\end{array}$ & $\begin{array}{l}\text { Strongly } \\
\text { Agreed }\end{array}$ & Agreed & Disagreed & $\begin{array}{l}\text { Strongly } \\
\text { Disagreed }\end{array}$ \\
\hline 1. & Teachers can send and reply E-mails & (20) $25.0 \%$ & $\begin{array}{l}(30) \\
37.5 \%\end{array}$ & (20) $25.0 \%$ & (10) $12.5 \%$ \\
\hline 2. & Can type using Microsoft word & (10) $12.5 \%$ & $\begin{array}{l}(20) \\
25.5 \%\end{array}$ & (30) $37.5 \%$ & (20) $25.0 \%$ \\
\hline 3. & Uses social media on daily basis & (40) $50.0 \%$ & $\begin{array}{l}(30) \\
37.5 \%\end{array}$ & (8) $10 \%$ & (2) $2.5 \%$ \\
\hline 4. & Can navigate the internet & (10) $12.5 \%$ & $\begin{array}{l}(15) \\
18.75 \%\end{array}$ & $\begin{array}{l}(45) \\
56.25 \%\end{array}$ & (10) $12.5 \%$ \\
\hline 5. & Can open webpage & (5) $6.25 \%$ & $\begin{array}{l}(10) \\
12.5 \%\end{array}$ & (50) $40 \%$ & $\begin{array}{l}(15) \\
18.75 \% \\
\end{array}$ \\
\hline 6. & Can impute results on internet & (30) $37.5 \%$ & $\begin{array}{l}(20) \\
25.0 \%\end{array}$ & (20) $25.0 \%$ & (10) $12.5 \%$ \\
\hline 7. & Connection to data & (25) $31.25 \%$ & $\begin{array}{l}(30) \\
37.5 \%\end{array}$ & $\begin{array}{l}(25) \\
31.25 \%\end{array}$ & -- \\
\hline 8. & $\begin{array}{l}\text { Access and update software on } \\
\text { devices }\end{array}$ & -- & $\begin{array}{ll}(10) \\
12.5 \%\end{array}$ & (60) $75 \%$ & (10) $12.5 \%$ \\
\hline 9. & $\begin{array}{l}\text { Teachers can type and correct } \\
\text { assignments }\end{array}$ & (51) $6.25 \%$ & $\begin{array}{l}(10) \\
12.5 \%\end{array}$ & $\begin{array}{l}(45) \\
56.25 \%\end{array}$ & (20) $25.0 \%$ \\
\hline 10. & $\begin{array}{l}\text { Can identify and resolve problems } \\
\text { that occur on computer devices }\end{array}$ & -- & (5) $6.25 \%$ & $\begin{array}{l}55) \\
68.75 \% \\
\end{array}$ & (20) $25.0 \%$ \\
\hline
\end{tabular}

Table 2. E-Learning and its ability to enhance teaching of home economics

\begin{tabular}{|c|c|c|c|c|c|}
\hline & $\begin{array}{l}\text { How E-learning can Enhance } \\
\text { Teaching of Home Economics }\end{array}$ & $\begin{array}{l}\text { Strongly } \\
\text { Agreed }\end{array}$ & Agreed & Disagreed & $\begin{array}{l}\text { Strongly } \\
\text { Disagreed }\end{array}$ \\
\hline 1. & $\begin{array}{l}\text { E-learning helps to express } \\
\text { teaching better }\end{array}$ & $\begin{array}{l}(60) \\
75.0 \%\end{array}$ & $\begin{array}{l}(20) \\
25.0 \%\end{array}$ & -- & -- \\
\hline 2. & $\begin{array}{l}\text { Proposal and projects can be made } \\
\text { easy with students/ teachers' } \\
\text { communications on internet }\end{array}$ & $\begin{array}{l}(50) \\
62.5 \%\end{array}$ & $\begin{array}{l}(30) \\
37.5 \%\end{array}$ & -- & -- \\
\hline 3. & Suitable for practical classes & $\begin{array}{l}(55) \\
68.75 \%\end{array}$ & $\begin{array}{l}(25) \\
31.25 \%\end{array}$ & - & -- \\
\hline 4. & $\begin{array}{l}\text { Patterns of different shapes can be } \\
\text { adopted from the internet }\end{array}$ & $\begin{array}{l}(60) \\
75.0 \%\end{array}$ & $\begin{array}{l}(20) \\
25.0 \%\end{array}$ & -- & -- \\
\hline 5. & $\begin{array}{l}\text { Students can be given assignment } \\
\text { from the internet }\end{array}$ & $\begin{array}{l}50) \\
62.5 \%\end{array}$ & $\begin{array}{l}30) \\
37.5 \%\end{array}$ & -- & -- \\
\hline 6. & Aid students working on their own & $\begin{array}{l}(55) \\
68.75 \%\end{array}$ & $\begin{array}{l}(25) \\
31.25 \%\end{array}$ & -- & -- \\
\hline 7. & $\begin{array}{l}\text { New and modern food recipes can } \\
\text { be obtained through internet } \\
\text { services }\end{array}$ & $\begin{array}{l}(75) \\
93.75 \%\end{array}$ & (5) $6.3 \%$ & -- & -- \\
\hline
\end{tabular}


Table 3. How school management support E-Learning

\begin{tabular}{|c|c|c|c|c|c|}
\hline & School Management Support & $\begin{array}{l}\text { Strongly } \\
\text { Agreed }\end{array}$ & Agreed & Disagreed & $\begin{array}{l}\text { Strongly } \\
\text { Disagreed }\end{array}$ \\
\hline 1. & Provision of Computers & $25.0 \%$ & $\begin{array}{l}(30) \\
37.5 \%\end{array}$ & (20) $25 \%$ & $\begin{array}{l}(10) \\
12.5 \%\end{array}$ \\
\hline 2. & $\begin{array}{l}\text { Orientation on the use of } \\
\text { Internet facilities }\end{array}$ & (5) $6.25 \%$ & $\begin{array}{l}(15) \\
18.75 \%\end{array}$ & (40) $50.0 \%$ & $\begin{array}{l}(20) \\
25.0 \%\end{array}$ \\
\hline 3. & $\begin{array}{l}\text { Availability of multimedia } \\
\text { projects }\end{array}$ & -- & (5) $6.25 \%$ & (50) $62.5 \%$ & $\begin{array}{l}(25) \\
31.25 \%\end{array}$ \\
\hline 4. & $\begin{array}{l}\text { ICT training and re-training for } \\
\text { teachers }\end{array}$ & (20) $25.0 \%$ & $(30) 37.5 \%$ & $25.0 \%$ & $\begin{array}{l}(10) \\
12.5 \%\end{array}$ \\
\hline 5 . & $\begin{array}{l}\text { Provision of new and modern } \\
\text { devices }\end{array}$ & (2) $2.5 \%$ & (8) $10 \%$ & $75 \%$ & $\begin{array}{l}(10) \\
12.5 \%\end{array}$ \\
\hline 6. & $\begin{array}{l}\text { Availability of screen touch } \\
\text { electronic board }\end{array}$ & -- & -- & $(70) 87.5 \%$ & $\begin{array}{l}(10) \\
12.5 \%\end{array}$ \\
\hline 7. & $\begin{array}{l}\text { Availability of regular } \\
\text { electricity supply }\end{array}$ & (10) $12.5 \%$ & $\begin{array}{l}(20) \\
25.0 \%\end{array}$ & (50) $62.5 \%$ & $\begin{array}{l}(10) \\
12.5 \%\end{array}$ \\
\hline
\end{tabular}

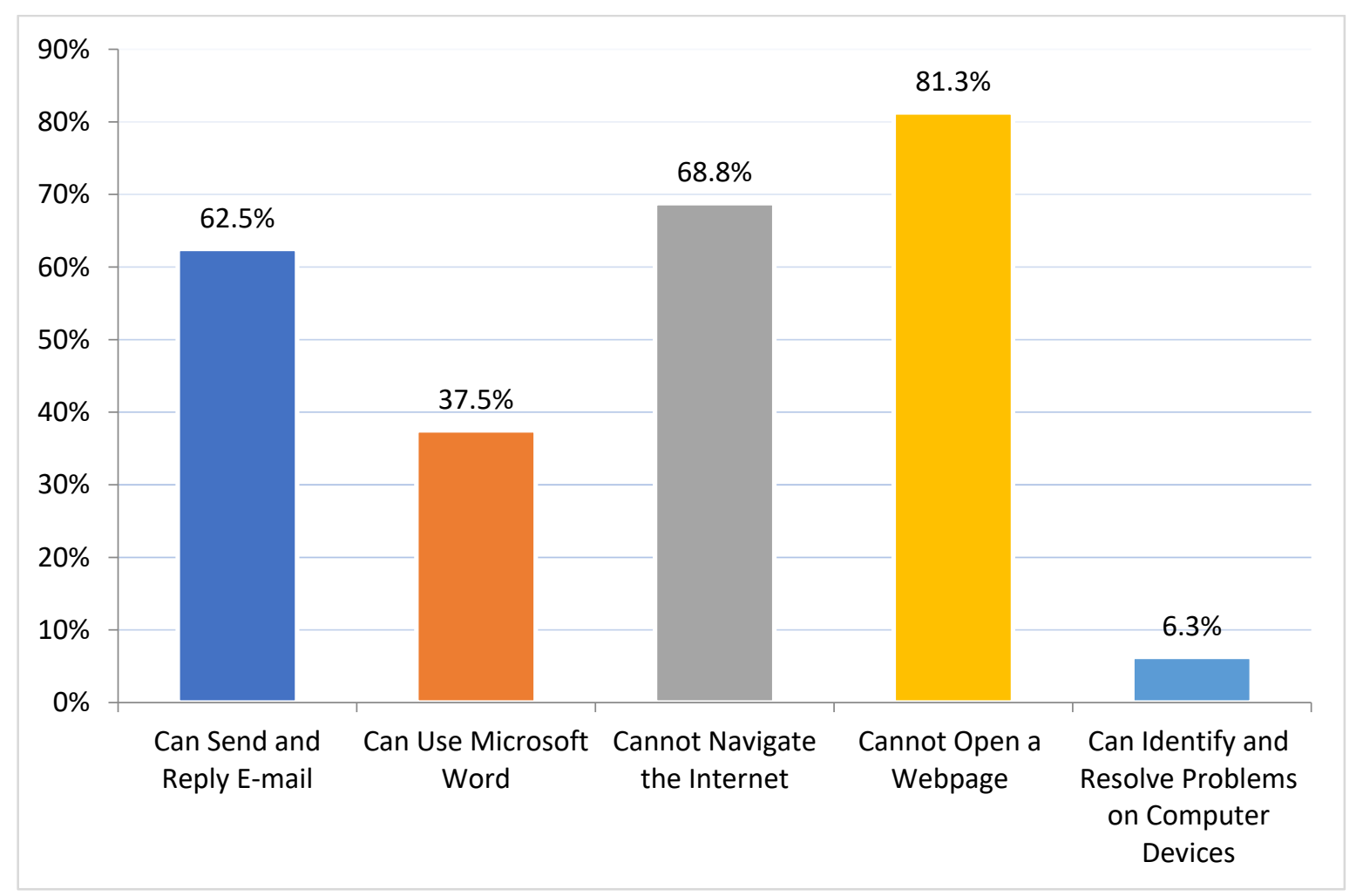

Figure 1. Home economics teachers' ability to use internet 


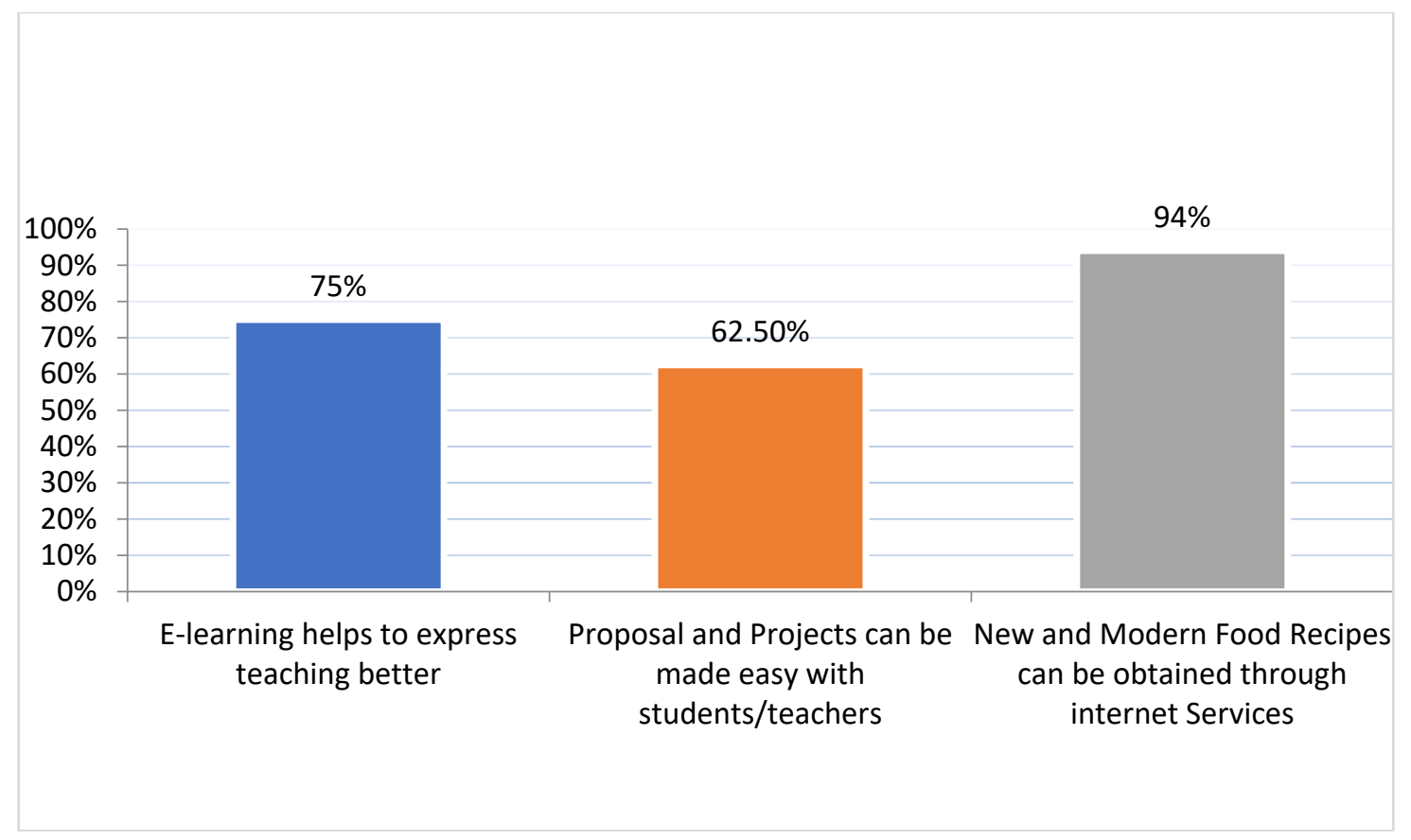

Figure 2. How E-Learning can enhance teaching of home economics

The final objective of the study was to ascertain if the school management support E-learning by providing Electricity, Internet facilities and orientation on the use of these facilities. The responses revealed that $62.5 \%$ agreed that the school management provides computers, $75 \%$ disagreed on the provision of orientation on the use of internet facilities, only $37.5 \%$ of the respondents agreed on the provision of stable electricity supply while majority of the respondents also disagreed on the provision of new and modern devices such as multimedia and screen touch board by the school management. These results show that despite the teachers showing some level on interest in utilizing e-learning tools for content delivery, the school management has not shown considerable level of commitment in the provision of these facilities. This further corroborates our statement of problem that the unavailability of these ICT facilities is a major challenge for the teachers in the schools (see Table 3).

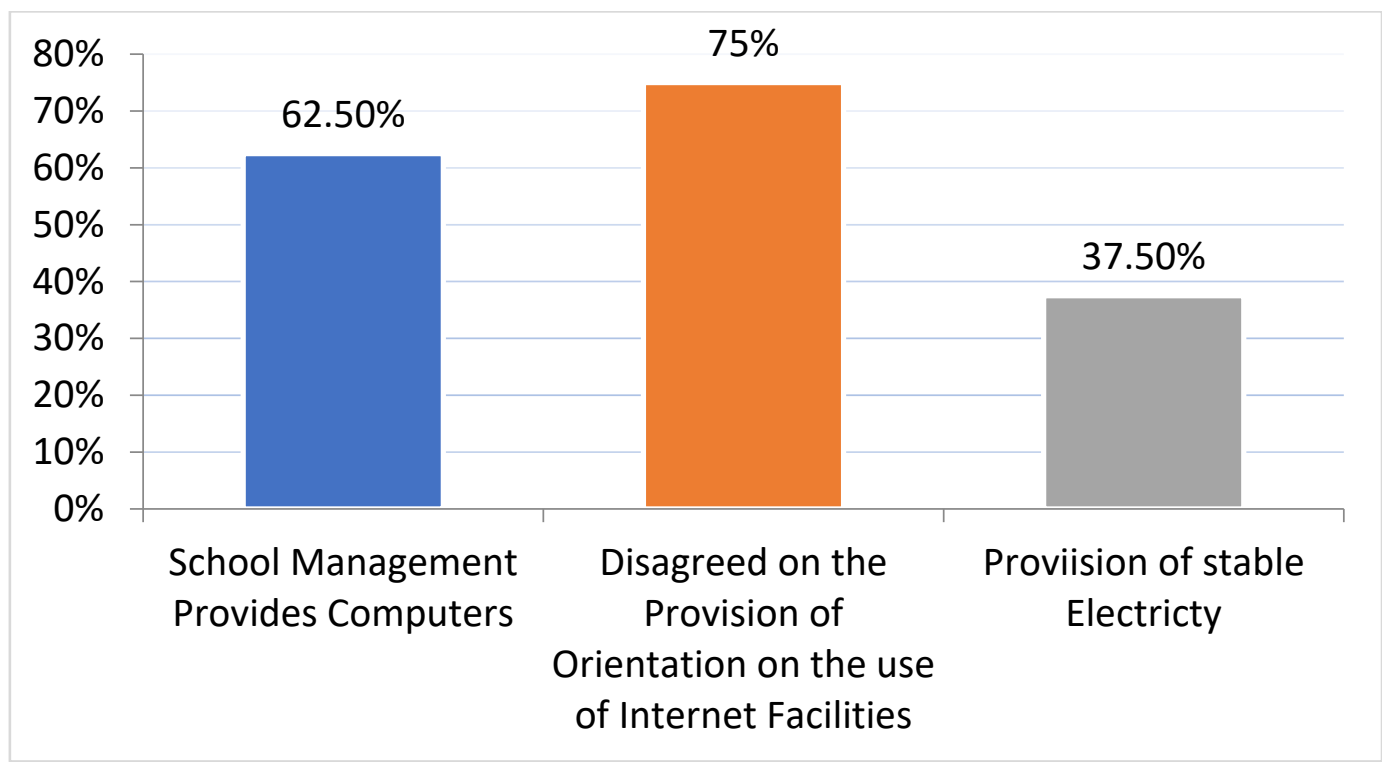

Figure 3. School management support 


\section{Conclusion}

The study has provided a comprehensive review of the Assessment of ICT Competences of Secondary School Teachers in Implementing E-Learning in Home Economics Education in Ogun state. Based on the findings of this study. It was concluded that there has to be an important focus on the provision of ICT facilities and active orientation of teachers on the use of these facilities.

\section{Policy Recommendations}

The study recommends as follows;

i. The school authority should provide well equipped computer laboratory for teaching and training.

ii. Availability of training and re-training of Home Economics teachers.

iii. Provision of functional ICT facilities such as, screen touch board, cheap data, etc.

iv. Home Economic teachers must be willing and open to ICT training.

v. School management should endeavor to fully computerize some vital school system such as, registration, fee payments, among others.

\section{References}

[1] Agbo Benjamin, Onaga Paul and Omeje Hyginus, (2018) Teachers' opinion on availability of e-learning opportunities for effective technical and vocational education and training (TVET) programme in tertiary institutions in South east Nigeria; International Journal of Vocational and Technical Education: Vol. 10(1), pp. 1-6

[2] Allen, M.W., (2003). Guide to e Learning: Building Interactive, Fun and Effective Learning Program for any Company. New jersey: John Wiley and Sons.

[3] Anyakoha, E., (2015) Home management for schools and colleges: Africana First Publishers PLC, Onitsha, Nigeria.

[4] Batchelor, S., Nocrish, P., (2005). Framework for Assessment of ICT Pilot Projects: Beyond Monitoring and t Applied Research. Washington: InforDev.

[5] Dargham, J., Saeed, D., \& Mcheik, H. (2013), " ELearning at school level: Challenges and Benefits ", The 13th International Arab Conference on Information Technology, 340-345.

[6] Micheal, A., Siyanbola W., Egbetokun A., Yesufu T. and Adewoyin, J., (2008); Pattern of computer and internet use among teachers in higher institutions in Nigeria: The Int. Journal of Learning Vol 15

[7] Okafor, U.P., Ejiofor, T., (2013); Utilization of elearning resources by lecturers of Vocational Technical
Education Departments in tertiary institutions in Enugu State; Int. Educ. Res. 12(2).

[8] Olson, J., \& Codde, J.R., \& deMaagd, K., \& Tarkelson, E., Sinclair, J., Yook, S., Egidio, R., (2011). An Analysis of e-Learning Impacts \& Best Practices in Developing Countries with Reference to Secondary School Education in Tanzania.

[9] Terande, T.J., (2012). Application of e-teaching and elearning in Nigerian educational system. Acad. Res. Int. 3(1):30-36. 